Int. J. Dev. Biol. 55: 237-242 (2011)

doi: $10.1387 / \mathrm{ijdb} .103151 \mathrm{ah}$

\title{
Mark Q. Martindale: shedding new light on developmental diversity
}

\author{
ANDREAS HEJNOL* \\ Sars International Centre for Marine Molecular Biology, Bergen, Norway
}

\begin{abstract}
The Saint-Petersburg Society of Naturalists awarded the 2009 "Alexander Kowalevsky Medal" to Mark Q. Martindale, Professor of Organismal Biology at the University of Hawaii and Director of the Kewalo Marine Laboratory, Honolulu. This international award inaugurated first in 1910 was re-established only in 2001. In memory of Alexander Onufrievich Kowalevsky, it is awarded to outstanding zoologists and embryologists who have made great contributions to the field of embryology and developmental biology from an evolutionary perspective. Mark $\mathbf{Q}$. Martindale has worked on a wide range of animals, mostly marine species, in contrast to many evo-devo researchers who often use a single "well-established" model organism. His work demonstrates how the insights gained by studying less "popular" animal taxa not only complement, but also significantly enrich our knowledge of the evolution of metazoan body plans and of the events that have led to the current animal diversity.
\end{abstract}

KEY WORDS: Mark Q. Martindale, Kowalevsky Medal, evolutionary developmental biology

\section{Mark Q. Martindale - a life fueled by curiosity for marine animals}

The awarding of the Kowalevsky Medal to Mark Q. Martindale is a perfect fit given that - similarly to Kowalevsky - Martindale has dedicated his professional life to studying the embryology of marine invertebrates. Both of these scientists have worked at various marine stations to gain access to a tremendous diversity of embryos; both have worked on many species of the same animal taxa (leech, phoronids, hemichordates, brachiopods, cephalopods, ctenophores) (Kowalevsky, 1866, 1867, 1871, 1883, 1897). Therefore, it is not surprising that both Kowalevsky and Martindale, each in his own way, have contributed greatly to our understanding of the evolution of animal organ systems and germ layers (e.g., mesoderm).

Mark Q. Martindale grew up in Cleveland, Ohio, where, even as a child, he was fascinated with marine animals. Working at a local pet store, he was able to expand his interests and maintained marine aquaria in his family home. He also learned SCUBA (Self Contained Underwater Breathing Apparatus) diving and was able to observe these animals in their natural setting. As an undergraduate student, he studied biology under the influential mentorship of John B. Morrill at the New College of the University of South Florida. Among colleagues of Mark, who worked in John Morrill's lab at that time, were such developmental biologists as
Chris Q. Doe, Randy T. Moon and Andrew Ransick.

After finishing his B.A. in 1981, Mark began his graduate studies at the University of Texas (Austin), in the lab of Gary Freeman - also a Kowalevsky Medal recipient (2001) - studying the development of ctenophores, which remain his favorite model organisms. He finished his Ph.D. in 1985 (Thesis: Martindale, 1985) and undertook a short-term postdoctoral training working on Medaka in Stephen Meier's lab, before Meier's untimely death in 1986. For a second postdoc, he moved to the Harvard Medical School in Boston (Massachusetts) and joined Marty Shankland's laboratory to work on leech development. In 1990, Mark became an Assistant Professor at the University of Chicago, remaining there until 1998, when he took his present position at the University of Hawaii, where he became Professor of Organismal Biology and Director (since 2005) of the Kewalo Marine Laboratory (Fig. 1).

During his career Mark has visited many marine laboratories for both research and teaching. He taught every summer since 1999 in the prestigious Embryology course at the Marine Biological Laboratory (Woods Hole, Massachusetts), has led the Comparative Embryology Course at the University of Washington's Friday Harbor Laboratories (Friday Harbor, Washington), and has participated as a lecturer in courses at the Duke University Marine Laboratory in Beaufort (NC) and Sven Lovén Center in Kristineberg (Sweden). He has thus been involved in teaching many of the next

\footnotetext{
*Address correspondence to: Andreas Hejnol. Sars International Centre for Marine Molecular Biology, Thormøhlensgate 55, 5008 Bergen, Norway. Fax: +47 5558-4305. e-mail: andreas.hejnol@sars.uib.no
} 
generation of "evo-devo" researchers, and many of his former students and postdocs are now research group leaders: Steve $Q$. Irvine, John R. Finnerty, Elaine C. Seaver, Stephan Q. Schneider, Casey W. Dunn, Craig R. Magie, William E. Browne, as well as the author of this article. During his career Martindale has published over 100 highly influential peer-reviewed articles, including many in Nature and Science.

\section{Understanding developmental mechanisms}

Mark has been an experimental embryologist from the beginning. His initial work was done on the spiralian freshwater gastropod Lymnaea, in which he investigated the role of the D-quadrant during determination of the body axis in relation to the animalvegetal axis of the embryo (Martindale et al., 1985; Martindale, 1986b). During his PhD work, he switched organisms and began working on marine invertebrates. The results of his PhD thesis ("The role of ontogeny on the expression of adult symmetry properties in the ctenophore, Mnemiopsis mccradyi") stemmed from his experimental manipulations on embryos and adults greatly improved our understanding of the developmental biology of these enigmatic animals.

Following the tradition of experimental embryology, Mark applied new methods during his $\mathrm{PhD}$, such as laser cell ablation, to find developmental mechanisms that can play a role in the establishment of the body axes of the adult. From his PhD thesis, he published a series of experiments on ctenophore development before he took a brief hiatus from marine invertebrates to study mesoderm development in Medaka fish (Martindale et al., 1987). This excursion to the vertebrates did not last long, and Mark found himself back with invertebrates, doing experimental studies of leech neurogenesis and segmentation, a field that Kowalevsky also worked in (among a series of Mark's publications about different aspects of leech segmentation and neurogenesis is one publication in "Nature"; see (Martindale and Shankland, 1990).

Over the next two decades Mark Q. Martindale applied his experimental embryological expertise to study the mechanisms of embryonic axis determination and development of organ systems in a diverse range of taxa. Embryological manipulations in nemertean (Henry and Martindale, 1994a, 1994b), ctenophore (Martindale, 1986a; Martindale and Henry, 1997; Henry and Martindale, 2001, 2004), polychaete (Henry and Martindale, 1987), and mollusc (Henry et al., 2006) embryos led to important insights regarding the developmental potential of individual blastomeres and the ability of the embryo to regulate following cell ablations.

\section{There is no greater joy than labeling an embryonic cell and tracing its contribution to the developing organ- ism $^{\star 1}$}

Mark Q. Martindale first began using fluorescent dyes to trace the fate of single cells during his studies of nervous system development in leech. Given his previous work on marine invertebrates, it was not surprising that these experiments led to the idea of applying the method to study the fate of individual blastomeres of early cleavage stages in many species. The approach

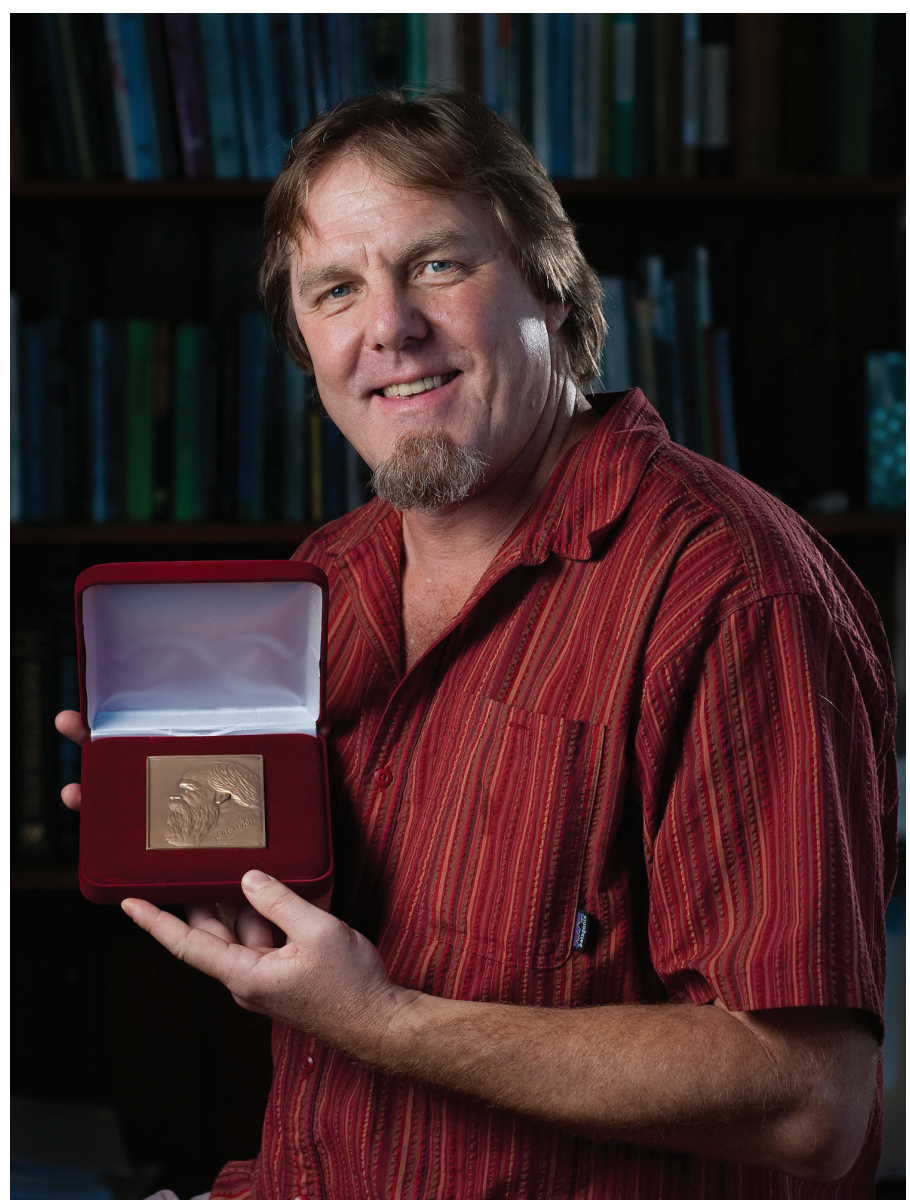

Fig. 1. Mark Q. Martindale with the Kowalevsky Medal. February 2010, Library of the Kewalo Marine Laboratory, Hawaii.

of tracing the fate of a cell in the early embryo and following how it gives rise to parts of the larva/adult goes back to the end of the $19^{\text {th }}$ century, when researchers including $E$. B. Wilson, E. G. Conklin, F. R. Lillie, and A. D. Mead investigated the cell-lineage of marine embryos by simple light microscopy. By careful observation they detected similarities in the cleavage pattern of animals with diverse adult body plans (e.g., molluscs, annelids and polyclad platyhelminthes, which all undergo spiral cleavage), and demonstrated how homologous cells give rise to similar body parts of the embryo (evidence of an underlying evolutionary connection, that E.B. Wilson (1898) referred to as "ancestral reminiscence"). However, cells can be followed by direct observation for only a limited extent before ciliary movements and/or the small size of the cells makes it impossible to identify them, and observations were previously limited to a relatively small number of examples. Mark's application of fluorescent, non-toxic, cell-tracing dyes, injected into cells of early stage living embryos, has overcome many of the limitations that earlier generations of researchers had encountered. Microinjection of fluorescent dyes into individual cells facilitated labeling smaller cells at later stages of development, and allowed identification of the progeny of the injected cells in fully developed larvae and adults (Fig. 2). Together these

\footnotetext{
${ }^{1}$ Comment from Mark Q. Martindale to the Kewalo PhD student Michael Boyle during his committee meeting.
} 
advances enabled the construction of much more detailed fate maps than had been previously delineated.

Using microinjection techniques and labeling of all the cells in the early embryo, Mark and his longtime collaborator, Jonathan Q. Henry, created detailed fate maps of the early embryos from a diversity of marine invertebrates and were able to make comparisons between different animal groups. Jonathan Q. Henry was also a graduate student in Gary Freeman's lab - a year ahead of Mark - where the two young scientists shared a fascination with the diversity of developmental patterns in different animals. This early friendship has led to nearly 25 years of collaboration. Mark and his "partner in crime", Jonathan Q. Henry have developed the method of dye injection into early blastomeres to perfection and have since then been on a mission. The Henry-Martindale team has traveled together to various marine stations in search of embryos from a broad range of taxa. Fate mapping in polyclad platyhelminthes (Boyer et al., 1996; Boyer et al., 1998), ctenophores (Martindale and Henry, 1997, 1999), nemerteans (Henry and Martindale, 1996a, 1996b, 1998; Maslakova et al., 2004a, b), acoels (Henry et al., 2000), hemichordates (Henry et al., 2001), polyplacophoran and gastropod molluscs (Henry et al., 2004; Hejnol et al., 2007) and phoronids (Freeman and Martindale, 2002) has greatly expanded our knowledge of animal embryos and their development.

These studies are delivering fundamental insights into animal relationships. Furthermore, this precise fate mapping is serving as a foundation for the application of molecular approaches to further unravel the evolution of animal diversity and to understand the evolution of the genome as it influences the phenotype. The sequence of a genome alone cannot replace studies on the living embryo. Fate mapping experiments require skills of embryo manipulations and are extremely time-consuming, but they provide a direct understanding of how the embryo functions.

\section{The evolution of animal body plans}

Descriptive and experimental studies of embryos not only provide information about developmental mechanisms, but also enable insights into the evolutionary history of animals. Contemporaneous with Martindale's studies on a variety of non-model embryos, exciting discoveries in the developmental biology of model organisms such as Drosophila and mouse showed that orthologous genes pattern similar body axes and organ systems in distantly related animals. These discoveries prompted a revival of the field of 'evo-devo' that integrated new molecular approaches into comparative developmental biology with the goal of understanding the evolution of animal body plans. In 1996, Mark co-organized the symposium "Evolution and Development: Pattern and Process" for the meeting of the Society of Integrative and Comparative Biology (SICB), one of the first symposia to focus on this re-emergent field, and he became program officer of the SICB Division of Evolutionary Developmental Biology when it formed in 2000.

To apply the discovery of conserved molecular patterning mechanisms in distantly related model systems to non-model invertebrates, Mark's research program expanded to employ studies of gene expression, including the 'iconic' Hox genes, which play a fundamental role in anterior-posterior patterning in bilaterians.
Continuing his postdoctoral work on leech, Mark, then an Assistant Professor at the University of Chicago, studied homeodomain gene expression during leech development (Master et al., 1996; Kourakis et al., 1997; Kourakis and Martindale, 2001). Expanding the list of animals in which the expression of Hox genes had been investigated, Mark's group studied the heterogeneous segmented polychaete Chaetopterus, to illuminate whether Hox genes are responsible for patterning the morphological boundaries in this annelid (Irvine et al., 1999; Irvine and Martindale, 2000). Since then, Mark's laboratory has investigated Hox gene expression in a variety of taxa, including cephalopods, acoels and cnidarians (Finnerty and Martindale, 1999; Lee et al., 2003; Finnerty et al., 2004; Ryan et al., 2007; Hejnol and Martindale, 2009).

In addition to axial patterning, Mark is also interested in the evolution of germ layers and organ systems. He was involved in comparative work about the role of the gene Distal-less in appendage formation (Panganiban et al., 1997), and investigated nervous system and digestive tract evolution in multiple animals. Clearly, Mark has been one of the leading scientists carrying out integrative studies in the field of evolution and development, and has developed the field further by pointing out the importance of studying a broad range of animals to understand the evolution of animal diversity.

\section{The genomic age - Nematostella et al.}

Understanding how the animal genome is transformed into a living organism and how the evolution of the genome is tied to the diversification of animals requires the acquisition of genomic data from beyond the traditional model systems that were the focus of initial sequencing projects. Recognizing this, Mark took the opportunity to initiate together with colleagues the genome sequencing of several non-traditional model organisms. Following this path, Mark was involved in establishing the anthozoan sea anemone, Nematostella vectensis, as a new cnidarian model system. Nematostella has distinct advantages over the dominant
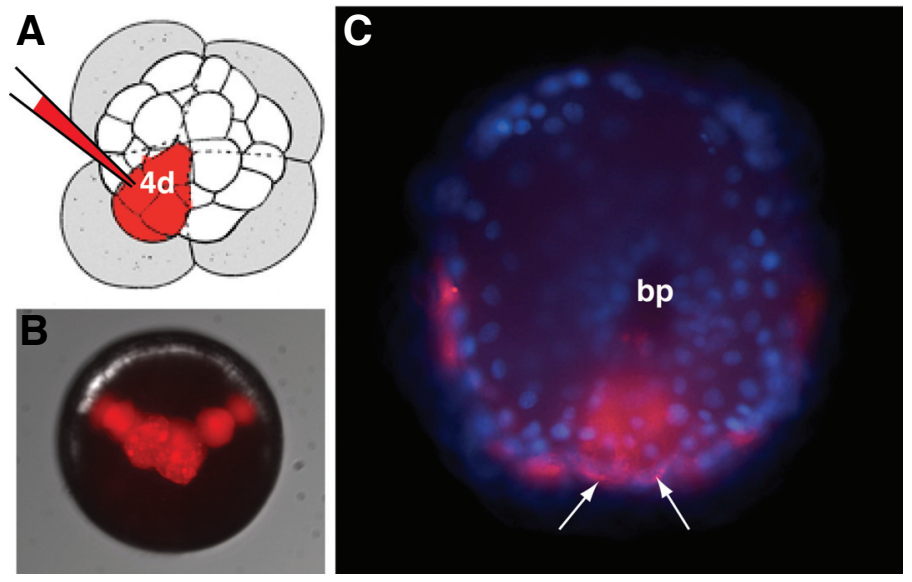

Fig. 2. Labeling and cell tracing in Crepidula fornicata (Gastropoda) embryos. (A) Scheme of injection of rhodamine-dextran dye solution into the mesentoblast $4 d$. (B) Dye-injected embryo two cell cycles later. (C) Advanced embryo in which the mesodermal bands are formed by the labeled mesoblasts (arrows). bp, blastopore. 
cnidarian model, the hydrozoan Hydra, in that it readily and inducibly undergoes sexual reproduction in the laboratory.

It was clear to Mark that this cnidarian system with its easily accessible embryonic material could facilitate insightful studies about the evolution of body axes, germ layers and organ systems. Employing Nematostella, Mark has since published numerous papers addressing each of these seminal topics. Taking the cnidarian embryo as an out-group to the bilaterians, Mark investigated genes that are expressed in the mesoderm of bilaterian animals in Nematostella. The finding that 'mesodermal' genes are expressed in the endoderm in cnidarians, which possess no distinguishable mesoderm, gave support for the evolutionary origin of the mesoderm from the endoderm (Martindale et al., 2004). Another surprising finding was that the 'simple' sea anemone possesses nearly all genes coding for WNT-factors (important signaling molecules involved in many developmental processes) that are present in chordates, even those WNT-genes that are lacking in model systems, such as Drosophila or $C$. elegans (Kusserow et al., 2005). It became clear that the genome of Nematostella carries much information pertinent to our understanding of animal evolution than its simple "radial" morphology at first suggested. With the intention of understanding the evolution of animal body plans, Mark is collaborating with Andreas Baxevanis from the NIH in sequencing the genome of the ctenophore, Mnemiopsis leidyi.

\section{Animal relationships}

Following his main goal, namely, to understand embryos and evolutionary changes in their development, Mark became involved not only in genome projects, but also in molecular phylogenetic analysis. Mark knows that for a proper interpretation of evolutionary changes, a phylogenetic framework is fundamental. In collaboration with Gonzalo Giribet (Harvard University) and others from the Assembling the Tree of Life, Team Protostome, funded by the National Science Foundation, he took advantage of large scale sequencing approaches to solve the phylogenetic relationships of animals. By tracing multiple genes in many organisms to reconstruct animal relationships, Mark's group in Hawaii has become the driving force behind several phylogenomic projects (Matus et al., 2006; Dunn et al., 2008; Hejnol et al., 2009). Mark's intention was to gain information on the evolution of animal organ systems and developmental patterns, such as segmentation, spiral cleavage, coelom formation and other processes, and to overcome the lack of resolution in the animal tree of life.

\section{Synopsis}

As outlined above, it is clear that the 2009 Kowalevsky Medal laureate, Mark $Q$. Martindale, is unique in the broad range of approaches he has pursued to understand the developmental mechanisms underlying the diversity of animal embryos. Instead of listing the $\sim 16$ animal phyla Mark has worked on, it is easier to list the ones he has not (yet) worked with, namely, tardigrades, gastrotrichs, gnathostomulids, nematodes, nematomorphs, kinorhynchs, rotifers, bryozoans, placozoans, sponges, and the loriciferans. It would indeed be surprising if many of these clades are not the subject of his future investigations. Even a brief

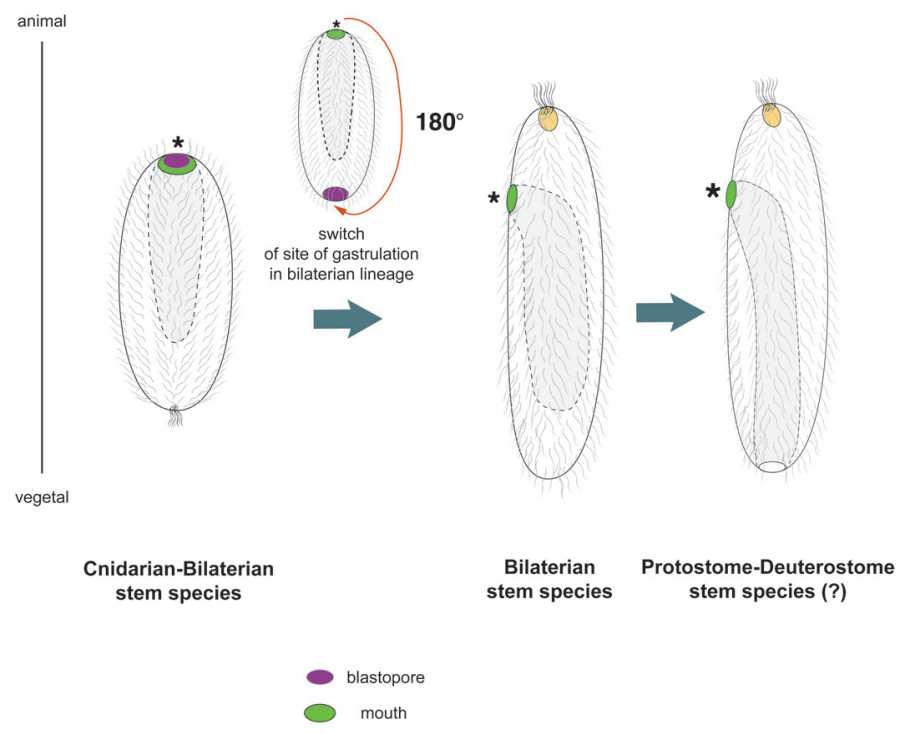

Fig. 3. Martindale's hypothesis about the early evolution of axial polarities during the transition of the Cnidarian-Bilaterian ancestor to the first Bilaterian. For details, see Martindale and Hejnol (2009).

analysis of his approaches (experimental embryology, cell lineage, fate mapping, molecular, genomic and phylogenetic approaches) on such a broad range of animals, leads us to conclude: Mark Q. Martindale knows embryos and embryonic principles. It is thus not surprising that over the years of working in the laboratory, educating students and discussing development with other researchers, he has developed an integrative hypothesis about the evolution of body plans. Of course, he sees it from the developmental perspective, as an embryologist who has handson experience with living material from the ocean. The identification of the cell in the early embryo to inject the fluorescent dye, tracing its fate through the process of gastrulation and observing its contribution to the larval or adult body deepens the understanding of animal embryos. These approaches focus on the fundamental characters of an embryo, the formation of polarity and axial properties, and the processes of gastrulation and germ layer formation, which build the animals' basic body.

In addition to these embryonic processes, Mark has investigated genes that play fundamental roles in animal-vegetal axis specification and gastrulation, such as beta-catenin and Dishevelled (Schneider et al., 2003; Wikramanayake et al., 2003; Lee et al., 2007; Henry et al., 2008, 2010). Comparing the development of different animals, Mark identified the animal-vegetal axis as the first and major axis along which the future body plan will be organized (Martindale, 2005). The synopsis of the insights into animal phylogenetic relationships (ctenophores and cnidarians as separate lineages, and acoelomorphs as the sister group to all remaining Bilateria), their developmental specifics, such as the site of gastrulation (ctenophores and cnidarians at the animal pole, all bilaterians at the vegetal pole) and the genes involved in the patterning of germ layers and body axis (Dishevelled, betacatenin, WNT and downstream transcription factors) led him to develop a testable scenario about the transition of the nonBilaterian into a bilaterian (Martindale and Hejnol, 2009) (Fig. 3).

\footnotetext{
${ }^{2}$ Mark finished his talks at several meetings and seminars about the evolution of body plans with this sentence.
} 
Mark's provocative message to students "Study embryos, not books"' is taken from Louis Aggasiz's famous exhortation, "Study nature, not books", which is emblazoned on the wall of the library at the Marine Biological Laboratory, where Mark attended the Embryology course, as a young graduate student, published his very first manuscript (Martindale and Brandhorst, 1984) and has since conducted much of his seminal research. Mark's statement is not an invective against reading, but rather an encouragement to the students to actually look with an open, sharp mind at the living material where there is a lot more to be learned than what is written in text-books.

Taken together, Mark Q. Martindale's impressive contributions to the field of comparative developmental biology and evodevo will surely only increase in its impact as future generations of researchers continue the endeavor of connecting the information in genomes to the biology, evolution and behavior of organisms.

\section{Acknowledgements}

The following people helped to improve the article: Tricia Murata shot the portrait of Mark, Kevin Pang, Yale Passamaneck, and Mark's friend and colleague, Jon Q. Henry, contributed with suggestions and improvements of the manuscript and Nadya Rimskaya-Korsakova translated Russian literature. I have to thank all members of the Kewalo Marine Laboratory who contributed to a wonderful, motivating atmosphere during my stay in the lab, and last but not least I thank Mark Q. Martindale for his support and the opportunity to work in his laboratory, to learn, investigate and discuss many aspects of evolutionary developmental biology.

\section{References}

BOYER, B.C., HENRY, J.J. and MARTINDALE, M.Q. (1998). The cell lineage of a polyclad turbellarian embryo reveals close similarity to coelomate spiralians. Dev Biol 204: 111-123.

BOYER, B.C., HENRY, J.Q. and MARTINDALE, M.Q. (1996). Dual origins of mesoderm in a basal spiralian: cell lineage analyses in the polyclad turbellarian Hoploplana inquilina. Dev Biol 179: 329-338.

DUNN, C.W., HEJNOL, A., MATUS, D.Q., PANG, K., BROWNE, W.E., SMITH, S.A., SEAVER, E., ROUSE, G.W., OBST, M., EDGECOMBE, G.D., SØRENSEN, M.V., HADDOCK, S.H., SCHMIDT-RHAESA, A., OKUSU, A., KRISTENSEN, R.M., WHEELER, W.C., MARTINDALE, M.Q. and GIRIBET, G. (2008). Broad phylogenomic sampling improves resolution of the animal tree of life. Nature 452: 745-749.

FINNERTY, J.R. and MARTINDALE, M.Q. (1999). Ancient origins of axial patterning genes: Hox genes and ParaHox genes in the Cnidaria. Evol Dev 1: 16-23.

FINNERTY, J.R., PANG, K., BURTON, P., PAULSON, D. and MARTINDALE, M.Q. (2004). Origins of bilateral symmetry: Hox and dpp expression in a sea anemone. Science 304: 1335-1337.

FREEMAN, G. and MARTINDALE, M.Q. (2002). The origin of mesoderm in phoronids. Dev Biol 252: 301-311.

HEJNOL, A. and MARTINDALE, M.Q. (2009). Coordinated spatial and temporal expression of Hox genes during embryogenesis in the acoel Convolutriloba longifissura. BMC Biol 7: 65.

HEJNOL, A., MARTINDALE, M.Q. and HENRY, J.Q. (2007). High-resolution fate map of the snail Crepidula fornicata: the origins of ciliary bands, nervous system, and muscular elements. Dev Biol 305: 63-76.

HEJNOL, A., OBST, M., STAMATAKIS, A., OTT, M., ROUSE, G.W., EDGECOMBE, G.D., MARTINEZ, P., BAGUÑA, J., BAILLY, X., JONDELIUS, U., WIENS, M., MLLER, W.E., SEAVER, E., WHEELER, W.C., MARTINDALE, M.Q., GIRIBET, G. and DUNN, C.W. (2009). Assessing the root of bilaterian animals with scalable phylogenomic methods. Proc Biol Sci 276: 4261-4270.

HENRY, J.J. and MARTINDALE, M.Q. (1987). The organizing role of the D quadrant as revealed by twinning in the polychaete, Chaetopterous variapedatus after the equalization of the first cleavage. Roux's Arch Dev Biol 196: 499-510.
HENRY, J.J. and MARTINDALE, M.Q. (1998). Conservation of the spiralian developmental program: cell lineage of the nemertean, Cerebratulus lacteus. Dev Biol 201: 253-269.

HENRY, J.Q. and MARTINDALE, M.Q. (1994a). Establishment of the dorsoventral axis in nemertean embryos: Evolutionary consideration of spiralian development. Dev Genetics 15: 64-78.

HENRY, J.Q. and MARTINDALE, M.Q. (1994b). Inhibitory cell-cell interactions control development in the embryos of Cerebratulus lacteus. Biol Bull 187: 238239.

HENRY, J.Q. and MARTINDALE, M.Q. (1996a). The establishment of embryonic axial properties in the nemertean, Cerebratulus lacteus. Dev Biol 180: 713-721.

HENRY, J.Q. and MARTINDALE, M.Q. (1996b). The origins of mesoderm in the equal-cleaving nemertean worm Cerebratulus lacteus Biol Bull 191: 286-288.

HENRY, J.Q. and MARTINDALE, M.Q. (2001). Multiple inductive signals are involved in the development of the ctenophore Mnemiopsis leidyi. Dev Biol238: 40-46.

HENRY, J.Q. and MARTINDALE, M.Q. (2004). Inductive interactions and embryonic equivalence groups in a basal metazoan, the ctenophore Mnemiopsis leidyi. Evol Dev 6: 17-24.

HENRY, J.Q., MARTINDALE, M.Q. and BOYER, B.C. (2000). The unique developmental program of the acoel flatworm, Neochildia fusca. Dev Biol 220: 285-295.

HENRY, J.Q., OKUSU, A. and MARTINDALE, M.Q. (2004). The cell lineage of the polyplacophoran, Chaetopleura apiculata: variation in the spiralian program and implications for molluscan evolution. Dev Biol 272: 145-160.

HENRY, J.Q., PERRY, K.J. and MARTINDALE, M.Q. (2006). Cell specification and the role of the polar lobe in the gastropod mollusc Crepidula fornicata. Dev Biol 297: 295-307.

HENRY, J.Q., PERRY, K.J. and MARTINDALE, M.Q. (2010). $\beta$-catenin and early development in the gastropod, Crepidula fornicata. Integr Comp Biol 50: 707719.

HENRY, J.Q., PERRY, K.J., WEVER, J., SEAVER, E. and MARTINDALE, M.Q. (2008). Beta-catenin is required for the establishment of vegetal embryonic fates in the nemertean, Cerebratulus lacteus. Dev Biol 317: 368-379.

HENRY, J.Q., TAGAWA, K. and MARTINDALE, M.Q. (2001). Deuterostome evolution: early development in the enteropneust hemichordate, Ptychodera flava. Evol Dev 3: 375-390.

IRVINE, S.Q., CHAGA, O. and MARTINDALE, M.Q. (1999). Larval ontogenetic stages of Chaetopterus: developmental heterochrony in the evolution of chaetopterid polychaetes. Biol Bull 197: 319-331.

IRVINE, S.Q. and MARTINDALE, M.Q. (2000). Expression patterns of anterior Hox genes in the polychaete Chaetopterus: correlation with morphological boundaries. Dev Biol 217: 333-351.

KOURAKIS, M.J. and MARTINDALE, M.Q. (2001). Hox gene duplication and deployment in the annelid leech Helobdella. Evol Dev 3: 145-153.

KOURAKIS, M.J., MASTER, V.A., LOKHORST, D.K., NARDELLI-HAEFLIGER, D. WEDEEN, C.J., MARTINDALE, M.Q. and SHANKLAND, M. (1997). Conserved anterior boundaries of Hox gene expression in the central nervous system of the leech Helobdella. Dev Biol 190: 284-300.

KOWALEVSKY, A. (1866). Entwicklungsgeschichte der Rippenquallen. Mém Acad St.-Pétersbourg 10: 1-28.

KOWALEVSKY, A. (1867). Anatomie und Entwicklung von Phoronis. Archiv Naturgesch 33.

KOWALEVSKY, A. (1871). Embryologische Studien an Würmern und Arthropoden. Mém Acad St.-Pétersbourg 16: 1-70.

KOWALEVSKY, A. (1883). Observations sur le développement des brachiopodes. Arch Zool Exp Gén 1: 57-76.

KOWALEVSKY, A. (1897). Études biologique sur les Clepsines. Mém Acad St.Pétersbourg 5: 1-15.

KUSSEROW, A., PANG, K., STURM, C., HROUDA, M., LENTFER, J., SCHMIDT, H.A., TECHNAU, U., VON HAESELER, A., HOBMAYER, B., MARTINDALE, M.Q. and HOLSTEIN, T.W. (2005). Unexpected complexity of the Wnt gene family in a sea anemone. Nature 433: 156-160.

LEE, P.N., CALLAERTS, P., DE COUET, H.G. and MARTINDALE, M.Q. (2003). Cephalopod Hox genes and the origin of morphological novelties. Nature 424: 1061-1065. 


\section{A. Hejnol}

LEE, P.N., KUMBUREgAMA, S., MARLOW, H.Q., MARTINDALE, M.Q. and WIKRAMANAYAKE, A.H. (2007). Asymmetric developmental potential along the animal-vegetal axis in the anthozoan cnidarian, Nematostella vectensis, is mediated by Dishevelled. Dev Biol 310: 169-186.

MARTINDALE, M.E. (1985). The role of ontogeny on the expression of adult symmetry properties in the ctenophore, Mnemiopsis mccrady (embryology, determination, regeneration, polar coordinate model, pattern formation), vol. PhD (ed., pp. 115. Texas: The University of Texas at Austin.

MARTINDALE, M.Q. (1986a). The ontogeny and maintenance of adult symmetry properties in the ctenophore, Mnemiopsis mccradyi. Dev Biol 118: 556-576.

MARTINDALE, M.Q. (1986b). The organizing role of the D quadrantin an equalcleaving spiralian, Lymnaea stagnalis, as studied by UV laser deletion of macromeres at intervals between third and forth quartet formation. Int J Invert Reprod Dev 9: 229-242.

MARTINDALE, M.Q. (2005). The evolution of metazoan axial properties. Nat Rev Genet 6: 917-927.

MARTINDALE, M.Q. and BRANDHORST, B.P. (1984). Translational changes induced by 1-methyladenine in anucleate starfish oocytes. Dev Biol 101: 512-515.

MARTINDALE, M.Q., DOE, C.Q. and MORRILL, J.B. (1985). The role of animalvegetal interaction with respect to the determination of dorsoventral polarity in the equal-cleaving spiralian, Lymnaea palustris. Roux's Arch Dev Biol 194: 281-295.

MARTINDALE, M.Q. and HEJNOL, A. (2009). A developmental perspective: changes in the position of the blastopore during bilaterian evolution. Dev Cell17: 162-174.

MARTINDALE, M.Q. and HENRY, J.Q. (1997). Reassessing embryogenesis in the Ctenophora: the inductive role of e1 micromeres in organizing ctene row formation in the 'mosaic' embryo, Mnemiopsis leidyi. Development 124: 1999 2006.

MARTINDALE, M.Q. and HENRY, J.Q. (1999). Intracellular fate mapping in a basal metazoan, the ctenophore Mnemiopsis leidyi, reveals the origins of mesoderm and the existence of indeterminate cell lineages. Dev Biol 214: 243-257.

MARTINDALE, M.Q., MEIER, S. and JACOBSON, A.G. (1987). Mesodermal metamerism in the teleost, Oryzias latipes (the medaka). J Morphol 193: 241-252.

MARTINDALE, M.Q., PANG, K. and FINNERTY, J.R. (2004). Investigating the origins of triploblasty: 'mesodermal' gene expression in a diploblastic animal, the sea anemone Nematostella vectensis (phylum, Cnidaria; class, Anthozoa). Development 131: 2463-2474.

MARTINDALE, M.Q. and SHANKLAND, M. (1990). Intrinsic segmental identity of segmental founder cells of the leech embryo. Nature 347: 672-674.

MASLAKOVA, S.A., MARTINDALE, M.Q. and NORENBURG, J.L. (2004a). Fundamental properties of the spiralian developmental program are displayed by the basal nemertean Carinoma tremaphoros (Palaeonemertea, Nemertea). Dev Biol 267: 342-360.

MASLAKOVA, S.A., MARTINDALE, M.Q. and NORENBURG, J.L. (2004b). Vestigial prototroch in a basal nemertean, Carinoma tremaphoros (Nemertea; Palaeonemertea). Evol Dev 6: 219-226.

MASTER, V.A., KOURAKIS, M.J. and MARTINDALE, M.Q. (1996). Isolation, characterization, and expression of Le-msx, a maternally expressed member of the $m s x$ gene family from the glossiphoniid leech Helobdella. Dev Dyn 207: 404-419.

MATUS, D.Q., COPLEY, R.R., DUNN, C.W., HEJNOL, A., ECCLESTON, H., HALANYCH, K.M., MARTINDALE, M.Q. and TELFORD, M.J. (2006). Broad taxon and gene sampling indicate that chaetognaths are protostomes. Curr Biol 16: R575-576.

PANGANIBAN, G., IRVINE, S.M., LOWE, C., ROEHL, H., CORLEY, L.S., SHERBON B., GRENIER, J.K., FALLON, J.F., KIMBLE, J., WALKER, M., WRAY, G.A. SWALLA, B.J., MARTINDALE, M.Q. and CARROLL, S.B. (1997). The origin and evolution of animal appendages. Proc Natl Acad Sci USA 94: 5162-5166.

RYAN, J.F., MAZZA, M.E., PANG, K., MATUS, D.Q., BAXEVANIS, A.D., MARTINDALE, M.Q. and FINNERTY, J.R. (2007). Pre-bilaterian origins of the Hox cluster and the Hox code: evidence from the sea anemone, Nematostella vectensis. PLoS One 2: e153.

SCHNEIDER, S.Q., FINNERTY, J.R. and MARTINDALE, M.Q. (2003). Protein evolution: structure-function relationships of the oncogene beta-catenin in the evolution of multicellular animals. J Exp Zool B Mol Dev Evol 295: 25-44.

WIKRAMANAYAKE, A.H., HONG, M., LEE, P.N., PANG, K., BYRUM, C.A., BINCE J.M., XU, R. and MARTINDALE, M.Q. (2003). An ancient role for nuclear betacatenin in the evolution of axial polarity and germ layer segregation. Nature 426: 446-450.

WILSON, E.B. (1898). Considerations of cell-lineage and ancestral reminiscence. Annals N Y Acad Sci 11: 1-27. 
Further Related Reading, published previously in the Int. J. Dev. Biol.

See our recent Special Issue Placenta edited by Joan S. Hunt and Kent L. Thornburg at: http://www.ijdb.ehu.es/web/contents.php?vol=54\&issue=2-3

Roles of Src family kinase signaling during fertilization and the first cell cycle in the marine protostome worm Cerebratulus Stephen A. Stricker, David J. Carroll and Wai L. Tsui Int. J. Dev. Biol. (2010) 54: 787-793

Michael Akam and the rise of evolutionary developmental biology

David L. Stern and Rachel E. Dawes-Hoang

Int. J. Dev. Biol. (2010) 54: 561-565

Peter Holland, homeobox genes and the developmental basis of animal diversity Sebastian M. Shimeld

Int. J. Dev. Biol. (2008) 52: 3-7

Induction of reverse development in two marine Hydrozoans

Jürgen Schmich, Yulia Kraus, Doris De Vito, Daria Graziussi, Ferdinando Boero and Stefano Piraino Int. J. Dev. Biol. (2007) 51: 45-56

Evolutionary embryology resurrected in Japan with a new molecular basis: Nori Satoh and the history of ascidian studies originating in Kyoto during the 20th century Shigeru Kuratani, Hiroshi Wada, Rie Kusakabe And Kiyokazu Agata Int. J. Dev. Biol. (2006) 50: 451-454

Putting evo-devo into focus. An interview with Scott F. Gilbert Alexander T. Mikhailov

Int. J. Dev. Biol. (2005) 49: 9-16

From development to evolution: the re-establishment of the «Alexander Kowalevsky Medal».

Alexander T Mikhailov and Scott F Gilbert

Int. J. Dev. Biol. (2002) 46: 693-698

Ecological regulation of development: induction of marine invertebrate metamorphosis. Daniel Jackson, Sally P Leys, Veronica F Hinman, Rick Woods, Martin F Lavin and Bernard M Degnan

Int. J. Dev. Biol. (2002) 46: 679-686

5 yr ISI Impact Factor $(2009)=3.253$
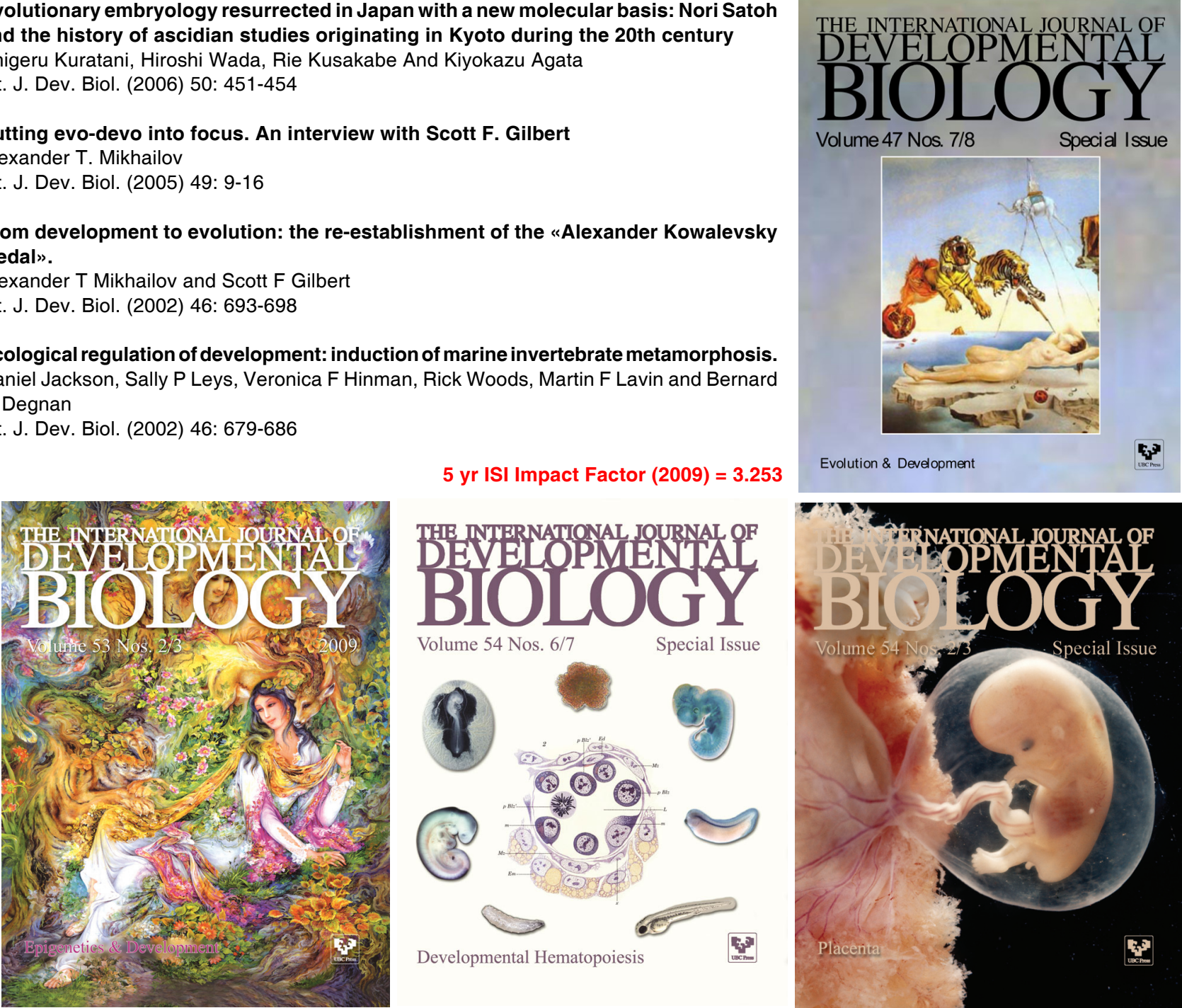

Volume 54 Nos. $6 / 7$

Special Issue
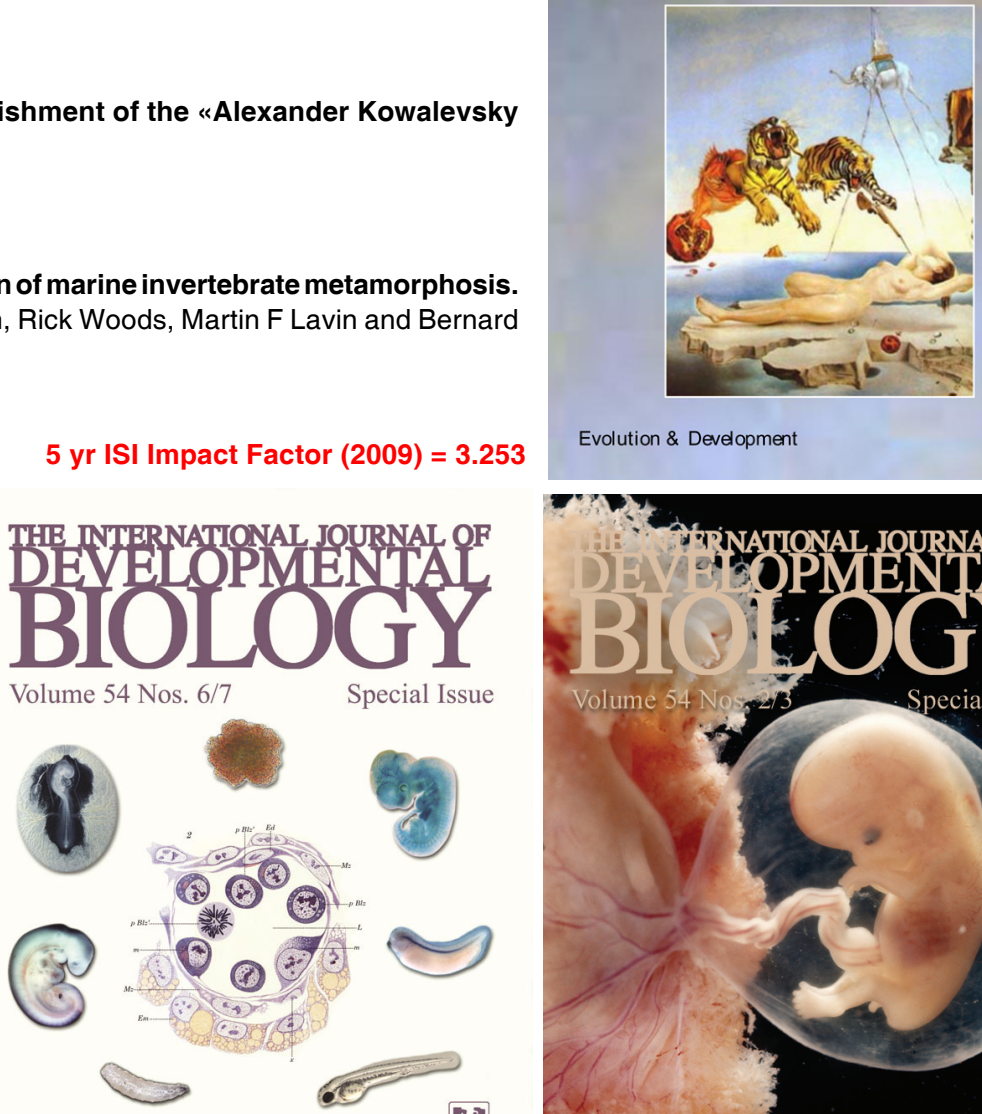

Evolution \& Development

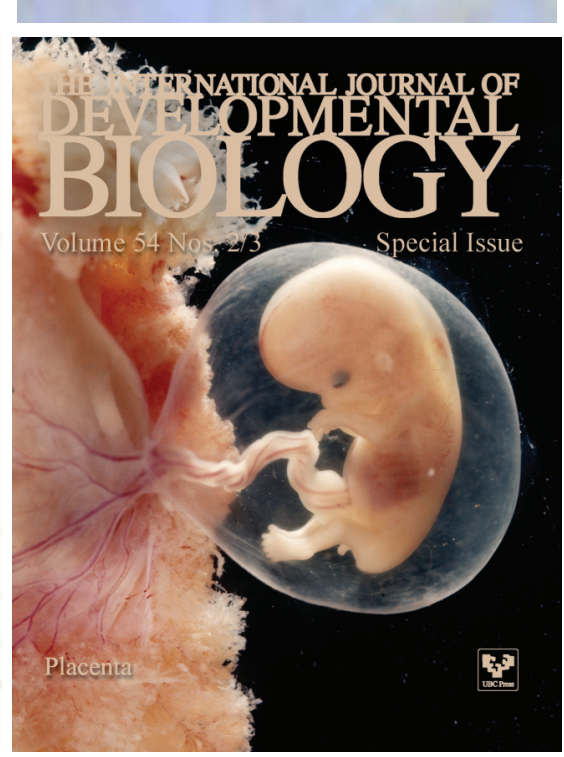

